\title{
Adaptation of the Body Image after Breast Cancer Questionnaire in the Polish context: factorial structure and validity of the scale
}

\begin{abstract}
BACKGROUND
Valid assessment of body image is salient in therapy and rehabilitation of women suffering from breast cancer. Adequate instruments are still lacking in this domain. To overcome this limitation two aims were formulated in the study. First, we tested the factorial structure of the Body Image after Breast Cancer Questionnaire (BIBCQ) developed by Baxter (1998) in Canada, in the Polish context. Then, we tested the construct validity of the scale. The scale is based on a multidimensional concept of the body image of chronically ill individuals proposed by Vamos (1993).
\end{abstract}

\section{PARTICIPANTS AND PROCEDURE}

A group of 270 women at the mean age of 55 (range of 23-81) with breast cancer who underwent conservation, mastectomy, or lumpectomy surgery was sampled in the Amazonki community.

\section{RESULTS}

Confirmatory factor analysis was used to test the factorial structure of the instrument. To test the convergent validi-

\begin{abstract}
ty, scales assessing body self, body image, self-esteem, and depression were used. Divergent validity was analyzed in the context of the social desirability construct. Discriminant validity was based on comparisons between women who had undergone lumpectomy or mastectomy surgery. The results showed that within two out of six subscales proposed by Baxter, two additional subscales had to be distinguished. However, some differences in comparisons with previous validation studies were also found.
\end{abstract}

\section{CONCLUSIONS}

The BIBCQ scale was found to be a valid multidimensional tool of body image assessment in the Polish context. The results are discussed in terms of cross-cultural differences in body image perception in breast cancer patients and guidelines for the scale's implementation in the Polish context.

\section{KEY WORDS}

body image; breast cancer; confirmatory factor analysis; scale validation 


\section{BACKGROUND}

Body image is pan-culturally related to quality of life, especially in its psychological aspect (Derbis, 2000, 2007; Kowalik, 2000; Montazeri, 2008). From the cultural perspective body image is the domain of interest more for women compared to men (Schier, 2009). From their birth, especially in traditional cultures, girls are evaluated by others through the lens of their appearance and its conformity to prevalent cultural standards. The standard of feminine body image is frequently exposed in mass media and the mainstream culture. Children are socialized in these standards early on by playing with Barbie dolls and watching TV commercials where women's bodies are unnaturally slim and equipped with the attributes of femininity, such as big breasts or lips. Thus some attributes of a woman's body are more crucial for body image and self than others. Women's breasts seem to be an important attribute of femininity; therefore when their perception is distorted by cancer it may seriously impair the body image of an ill woman.

The body image has been proved to be related to the development of the body self construct and the process of rehabilitation of individuals whose body appearance has been changed by illness, injury or medically often life-conserving surgery (Kowalik, 2007, 2009; Stavrou et al., 2009). The body image and the body self are described in the literature as multidimensional constructs (e.g., Ben-Tovim \& Walker, 1991; Cash, 2004; Cash \& Pruzinsky, 1990; Głębocka \& Kulbat, 2005; Kowalik, 2009; Lipowska \& Lipowski, 2013; Mirucka, 2003, 2005; Slade, 1994; Vamos, 1993). Although the two constructs differ, they are also interrelated (Izydorczyk \& Bieńkowska, 2008; Lipowska \& Lipowski, 2013; Mirucka \& Sakson-Obada, 2013). Generally, the body image is treated as a component of the body self, integral for self-image. Even though the construct is integral for self in the lifetime, its temporal (in)stability depends on domain, context, situation and time. Therefore, the body image has to be defined and assessed within the narrow domain of interest or situational context, rather than as a general construct ascribed to an individual. One of these contexts refers to the body image of women with breast cancer targeted in this study.

In general, two domains should be distinguished within the body image individuals maintain. First, it is the mental representation of own body attributes, such as the size, shape and the spatial location of body elements, which is usually self-evaluated in reference to socially desirable standards. The second domain relates to the psychological importance of these attributes, namely feelings/affect and cognitions related to each attribute separately and in their combinations. The psychological importance of life-threatening and cancer-related changes in body attributes (e.g., breast) probably matters more for women with breast cancer than the aspect related to their mental representation of body attributes (e.g., size). Illness and its medical treatment, often accompanied by surgery and hormonal therapy, may evoke multifold changes in body perception of an ill woman, including sensory changes within the breast, chest, armpit or arm, but also in feelings of sexual attractiveness and comfort during sexual intimacy (Fallbjörk, Rasmussen, Karlsson, \& Salander, 2013; Paterson, Lengacher, Donovan, Kip, \& Tofthagen, 2016). Breast conservation or mastectomy surgery may trigger more global problems within body image, identity, mood, self-esteem, sexuality, self-satisfaction, and decrease in life satisfaction. According to Al-Ghazal, Fallowfield and Blamey (2000), 91.00\% of women after breast-conservation surgery and $80.00 \%$ of those who underwent breast reconstruction were less than moderately satisfied with their bodies. The more invasive the treatment is, the less satisfied women are regarding their body and well-being. However, many researchers indicate (e.g., Ashing-Giwaa, Padilla, Bohorqueza, Tejeroa, \& Garcia 2006; Fung, Lau, Fielding, Or, \& Wai, 2001; Kissane et al., 1998; Pinto \& Trunzo, 2004; Schou, Ekeberg, Sandvik, Hjermstad, \& Ruland, 2005) that women who underwent breast-conservation surgery have a better body image, fewer body-change-related worries and feel more accepted by their spouses compared to women after mastectomy. Moreover, supplementary treatment in breast cancer patients may introduce additional health and appearance distortions relevant for body image. Among these, hair loss strongly impairs body esteem, although it depends on the attitude to this problem the woman adopts (Baxley, Kendrick, \& Brown, 1984; Boehmke \& Dickerson, 2005). While some women view their hair loss as a sign of courage and a source of pride, others perceive it as a traumatic experience seriously undermining their identity. Weight gain is another problem which may affect body esteem of patients. Goodwin et al. (1999) revealed in their study on 545 women with breast cancer that $84.00 \%$ of them gain $1.60 \mathrm{~kg}$ on average immediately after the cancer diagnosis.

Although the literature describing the effects of breast cancer on women's health is extensive, research on its effects on body image is still lacking. One reason is the lack of adequate instruments for body image assessment. Although their number has increased recently, instruments adequate for women with breast cancer are still needed. The European Organisation for Research and Treatment of Cancer (EORTC) introduced the EORTC QLQ-C30 including the module BR-23 (EORTC) for women with breast cancer, which is currently commonly used in this domain. However, this subscale is limited as it assesses only narrow aspects of the body image. Another, more extended and promising scale used in the field
Adaptation of Body Image after Breast Cancer Questionnaire in the Polish context 
is the Body Image after Breast Cancer Questionnaire (BIBCQ) proposed by Baxter (1998).

\section{THE BODY IMAGE AFTER BREAST CANCER QUESTIONNAIRE}

The BIBCQ scale is based on a multidimensional concept taking into account various aspects of the body image of chronically ill individuals proposed by Vamos (1993). The author stresses that four aspects need to be considered when analyzing the situation of chronically ill individuals: (1) Comfort addressing body related changes biased by illness, including pain, fatigue and nausea; (2) Competence referring to behaviors and cognitions evoked by changes in individual mobility and sexual functioning; (3) Appearance related to physical changes biased by illness and treatment procedures; (4) Predictability based on the illness time-span stability, including personal estimation of mood, and evaluation of age-related appropriateness of dysfunction occurrence. Referring to this framework, we assume in the present study that the body image of women experiencing breast cancer develops as the outcome of body-related experiences, including pain, fatigue, adverse changes in cognitive and biological functioning, and appearance biased by illness and/or its treatment.

Baxter (1998) and Baxter in collaboration with colleagues (Baxter et al., 2006) developed the scale to assess the long-term effects of breast cancer on the body image in multiple domains. Based on the framework of Vamos, the authors carried out the study aiming to develop the scale. Interviews with women with breast cancer and field experts in Canada were the basis from which the final item-set of the BIBCQ was developed. The authors proposed the BIBCQ scale's structure based on exploratory factor analysis carried out on the large item pool which was reduced finally to 53 items indicative for six body image domains/subscales: vulnerability, body stigma, limitations, body concerns, transparency, and arm concerns (Baxter, 1998) (see Appendix).

Vulnerability items assess vulnerability of the body to illness and cancer, feelings of invasion of the body, and a loss of trust in one's body as a healthy and functioning organism. More than half of the body stigma items loaded positively, while less than half negatively with the factor in the study of Baxter (1998). Positively loading items sample feelings of a need to keep the body hidden and avoid physical intimacy (items' endorsement indicates a high level of body stigma). Negatively loading items were indicative of feelings of comfort with nude appearance and sexual attractiveness (items' endorsement indicates low levels of body stigma). The positive and negative item loadings were also reported by Baxter within the limitations subscale. The first indicate an increased sense of limitation, while the others indicate a lesser sense of limitation. The body concerns items assess a general positive view of general body appearance. A sense of concern about the obviousness of cancer related changes to appearance or the ability of others to detect such changes is assessed by items of the transparency subscale. Finally, the arm concerns subscale proposed by the author includes positively and negatively loaded items. Positively loading items indicate a greater, whereas negatively loading items indicate a lesser degree of arm symptoms and concerns in women with breast cancer.

As some items were more suited to a frequency measure, and others for an agreement measure, two response formats were finally distinguished within the BIBCQ item set. Type one statements are indicative of (dis)agreement (items 1 to 28), while type two statements assess the frequency of behaviors or feelings of interest (items 29 to 53). The authors reported the BIBCQ reliability referring to internal consistency and test-retest time stability of results in the Canadian sample. The reliability of all subscales was acceptable and $\alpha$ coefficients of subscales ranged from .75 to .86 in the Canadian sample (Baxter, 1998). The test-retest stability as indicated by the difference in $\alpha$ coefficients between Time 1 and Time 2 assessments were: -.03 for vulnerability, .01 for body stigma, -.02 for limitations, -.01 for body concerns, and -.05 for transparency and arm concerns (Baxter et al., 2006).

\section{AIMS OF THE STUDY}

One's body image has crucial significance for individual quality of life and the course of treatment of women with breast cancer. This type of cancer ranks as the first among cancer diseases diagnosed in the population of women in Poland (Statistical Office in Krakow, 2012). There is a lack of body image assessment instruments in the Polish context targeting the specific group of women with breast cancer. Therefore we set out in the present study to test the validity of the BIBCQ scale in the Polish context in two areas. In Study 1 we tested the factorial structure of the BIBCQ item-set in the sample of Polish women experiencing breast cancer. In Study 2, we tested the construct (convergent and divergent) and discriminant validity of the scale in the Polish context.

\section{STUDY 1}

Previous studies on body image revealed that it is a multifactorial construct with between 2 and 7 factors (Baxter, 1998). Differences in item content and samples may bias these differences. Thus Baxter (1998) suggests that factorial structure should not be treated as conclusive but rather as hypothesis 
generating and the BIBCQ factorial structure should be repeated independently by other investigators in different populations of women with breast cancer using exploratory and confirmatory factor analysis. To date the BIBCQ scale has been tested not only in the Canadian context, but also in Chinese (Zhang et al., 2014) and Brazilian (Goncalves et al., 2014) samples. These studies revealed differences in the scale structure outside of a Canadian (Western) sample, indicating that careful investigation of its structure should be carried out in non-Canadian cultures. Furthermore, different psychometric properties were also found in Canadian (Boquiren, Esplen, Wong, Toner, \& Warner, 2013) and non-Canadian samples across studies (Chen et al., 2010; Kanatas et al., 2012).

The present study aimed to confirm or, if necessary, to investigate the factorial structure of the BIBCQ scale proposed by Baxter. For this purpose, confirmatory, and if necessary exploratory, factor analyses were implemented. For these reasons and considering the sample size, the present study should be treated as preliminary and the resulting description of a factorial structure of the BIBCQ as a solution which needs further investigation in the Polish context.

\section{PARTICIPANTS AND PROCEDURE}

\section{Measure}

The Body Image Breast Cancer Questionnaire consists of 45 items and an additional 6 items addressed to women who are not missing a breast due to lack of surgery or successful conservation/reconstruction surgery (lumpectomy - L items); and 2 items addressed to women who after the surgery are missing one or both breasts (mastectomy - M items). The questionnaire assesses the long-term impact of the breast cancer on the woman's body image.

The 6 subscales vary in the number of items included, where: Vulnerability has 11 general items and $1 \mathrm{~L}$ item; Body stigma has 11 general items and $4 \mathrm{~L}$ and $1 \mathrm{M}$ items; Limitations has 8 general items; Body concerns has 6 general items; Transparency has 5 general items and $1 \mathrm{M}$ item; and Arm concerns has 4 items and $1 \mathrm{~L}$ specific item. The scale has a 5-step Likert-response format different for Type I and Type II statements. The response format for Type I statements assesses respondents' agreement and ranges from (1) Strongly disagree to (5) Strongly agree, whereas Type II statements estimate the frequency of respondents' feelings, thoughts and behaviors and the response format ranges from (1) Never/almost never to (5) Always/almost always.

The BIBCQ questionnaire was translated and back-translated from the English to the Polish version by three independent translators, two of whom had a psychological and one a linguistic background (Brislin, 1980). One questionnaire was developed based on three translation outcome item pools. This version was back-translated from Polish to English by a British psychologist. The Polish version of the scale was named Kwestionariusz do Badania Obrazu Ciała Kobiet $z$ Rakiem Piersi (KOC-RP).

\section{Participants}

Two hundred and seventy women after breast surgery were sampled. Their mean age ranged from 24 to $81(M=55.37, S D=9.21)$. Seventy-six percent of women had university or higher-school education and $50.00 \%$ of the sample had undergone breast surgery 5 years or more before the study sampling. They were recruited from the Amazonki community. The Amazonki community sampled in our study is part of the national Polish Amazons post-mastectomy women's social movement. Its aim is to use the traumatic experience of breast cancer survivors for creating a friendly community for cancer patients. Women participating in our study had undergone breast conservation surgery ( $n=72$; the age ranged between 30 and 81 with $M=52.68, S D=9.29$ ) or mastectomy surgery $(n=168$; the age ranged between 24 and 77 with $M=56.35, S D=9.29$ ), or lumpectomy surgery $(n=168$; the age ranged between 23 and 72 with $M=52.14, S D=8.20$ ). They were sampled during their community meetings.

The procedure of the present study was subjected to the evaluation of the Ethics Committee of authorities of the Provincial Hospital in Częstochowa. The President of the Federation of Associations of the Amazons and the head of the Oncological Surgery Ward of the hospital in Częstochowa, where women from the Amazonki community are hospitalized, were part of this Committee. The approval for the current research was established based on the decision of the Committee and proceeded before sampling of data.

\section{RESULTS OF STUDY 1}

\section{Statistical analyses}

Preliminary analyses of our data revealed non-normal uni- and multivariate distributions of variables. To reduce the problem, we performed mathematical transformations of data (logarithm and square root depending on the type of skewness) and based our analyses on robust statistics, namely Satorra-Bentler corrections (Satorra \& Bentler, 1994) and bootstrapped confidence intervals (Konarski, 2010). We also checked for multivariate outliers. We did not have missing values in the dataset. The main analyses were carried out based on confirmatory factor analysis (CFA). However, we decided that if the CFA
Adaptation of Body Image after Breast Cancer Questionnaire in the Polish context 
Romuald Derbis,

Anna

Machnik-Czerwik analysis did not reveal satisfactory parameters of our model fit, we would carry out exploratory factor analysis (EFA) and investigate the CFA-based modification indices to find the source of the problem and trace the best fitting scale structure. The final analysis confirming our structural solution will be based on CFA. Due to the limitations related to the sample size and the number of subscales and items-related parameters, we decided that separate analysis would be carried out for each of six BIBCQ subscales (vulnerability, body stigma, limitations, body concerns, transparency, and arm concerns). Nonetheless, two subscales - transparency and arm concerns - were tested in the one two-factor model. This decision was based on two reasons. First, both have four or five observable indicators (items) each of which would trigger in our analyses a drop in degrees of freedom. Secondly, both are related to particular parts of the body (breast and arm), not with the body or its perception in general.

Furthermore, in looking for the optimal structure of items, we also decided to investigate two possible sources of structural inhomogeneity of subscales. First, four out of six subscales have a mixed format of items, where scores of some items have to be key-reversed before their averaging or summarization into their subscale's score. This may trigger a drop in the model fit indexes. Second, the BIBCQ scale additionally includes Type I and Type II statements, which may also affect the model fit indexes within each of the tested models. Finally, the content of items is not always homogeneous within subscales, so content-based structure seems to be also a viable option which will be additionally tested if low model fit indexes are found not to be biased by type of statements or the key-reversed scoring procedure. Therefore, first we checked model fit parameters of each subscale in the structure proposed by the scale authors. Nonetheless, if this solution proved to be problematic we additionally parceled subscales' item pools due to both types of statements, the item format or the items' content.

Finally, we estimated reliability coefficients for subscales of the BIBCQ instrument. As analyses proposed in this paper were based on structural equation modeling of measurement models, we used composite reliability (omega coefficient) to calculate reliability values of latent factors (Raykov, 2001). Yet, due to the common use of Cronbach's $\alpha$ coefficient in psychological studies, we also reported respective reliability values.

Due to space limitations we will not report all parameters of our structural models; however, we can provide the information upon request directed to the first author of the paper. Only standardized factor loadings of items and subscales' structures will be visualized in figures. Analyses were carried out using the following packages for the R environment (R Core Team, 2014): 'lavaan' (Rossell, 2012), 'psych' (Revelle, 2011) and 'MVN' (Korkmaz, Goksuluk, \& Zararsiz, 2015).

\section{Vulnerability}

The model fit parameters of the one-factor vulnerability subscale indicated the mediocre model fit with RMSEA $=.088$; and CFI $=.910$. Thus, the two-factor model with Type I and Type II pools of statements was tested. Five Type I items of the vulnerability subscale ask about the body perception being aware of the breast cancer. This subscale was labeled body perception. Five Type II items ask about anger, worries, and anxious rumination about own health and the body. The sixth Type II item asks about the need for external support insuring about health. This subscale was labeled body worries. The model fit parameters, reported in Table 1, were reasonable (Kline, 2005). The standardized factor loadings visualized in Figure 1 were also good. The covariance between both latent factors of the subscale was very high, indicating strong overlap in the subscale's content.

Table 1

Fit parameters of the BIBCQ subscales' structural models with Satorra-Bentler correction in the Polish sample $(n=270)$

\begin{tabular}{|c|c|c|c|c|c|c|}
\hline Subscale & $d f$ & $\chi^{2}$ & RMSEA & $90 \% \mathrm{Cl}$ & $\mathrm{CFI}$ & TLI \\
\hline Vulnerability (2-factor) & 43 & 81.55 & .058 & $.039 ; .075$ & .958 & .947 \\
\hline Body stigma (2-factor) & 32 & 65.32 & .062 & $.041 ; .083$ & .956 & .938 \\
\hline Limitations & 19 & 34.38 & .055 & $.027 ; .081$ & .957 & .937 \\
\hline Body concerns & 8 & 12.55 & .046 & $.001 ; .086$ & .990 & .981 \\
\hline $\begin{array}{l}\text { Transparency and Arm } \\
\text { concerns }\end{array}$ & 24 & 51.70 & .065 & $.041 ; .090$ & .952 & .929 \\
\hline Transparency & 4 & 6.94 & .052 & $.001 ; .115$ & .990 & .974 \\
\hline Arm concerns & 1 & 2.84 & .083 & $.001 ; .001$ & .992 & .995 \\
\hline
\end{tabular}

Note. All $\chi^{2}$ values are significant at the level of $p<.001$. 


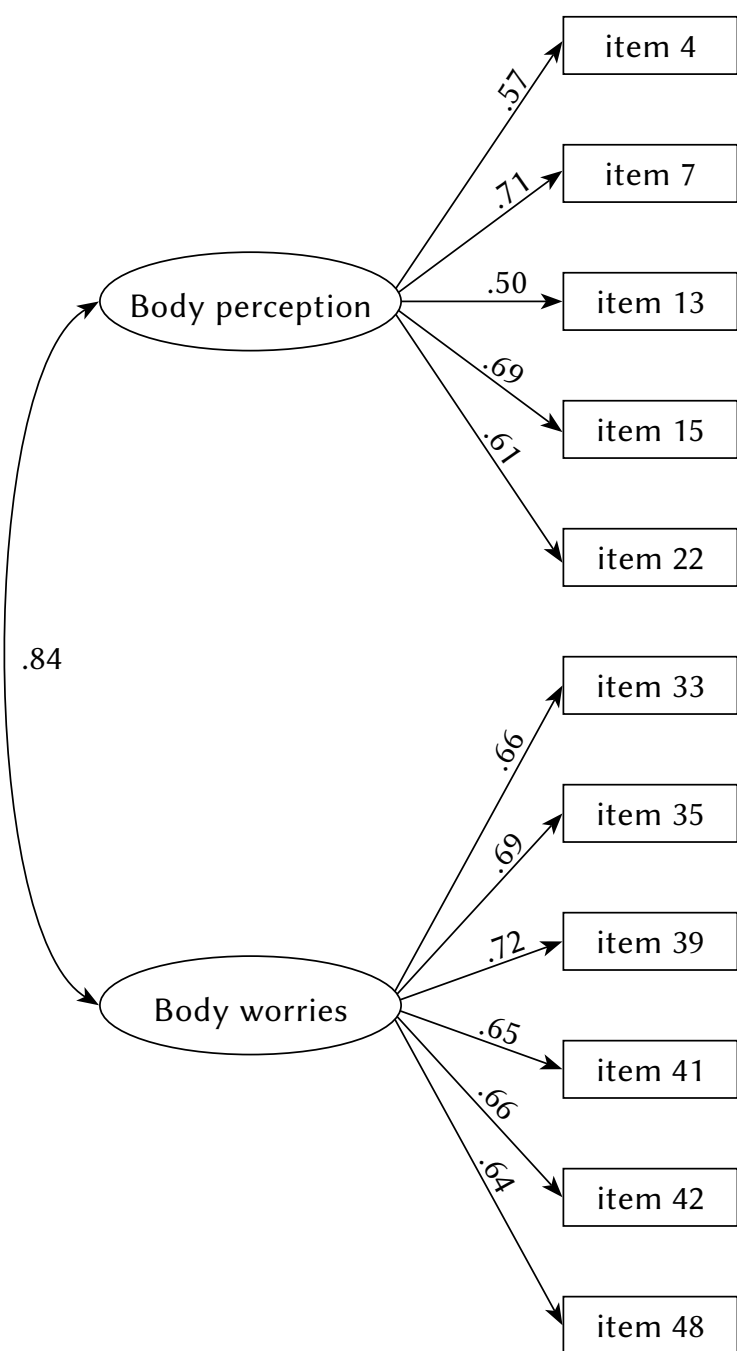

Figure 1. Factorial structure of the vulnerability subscale in the Polish sample.

\section{Body stigma}

First, we tested the model fit of the one-factor body stigma subscale. The parameters indicated unacceptable model fit with RMSEA $=.101$ and $\mathrm{CFI}=.846$. Parameters of the two-factor model with Type I and Type II item pools were also not acceptable; RMSEA $=.093$ and CFI $=.872$. To investigate the source of the problem we correlated the error terms of two items which had to be key-reversed (recoded) to obtain the subscale's total score. The improvement in the model fit parameters was not satisfactory $(\triangle \mathrm{CFI}=.004$, RMSEA change of -.001), indicating different reasons for structural problems. Thus we performed EFA analysis and investigated modification indices of our structural model. Based on these results and theoretical analysis of the items' content we tested the two-factor model. One factor, labeled body aversion (items 3, 9, 19, and 21), consisted of items indicative of aversion related to physical contacts (e.g., hugging), looking at/touching own scars; and feeling less feminine. The second factor, labeled body hiding (items 1,

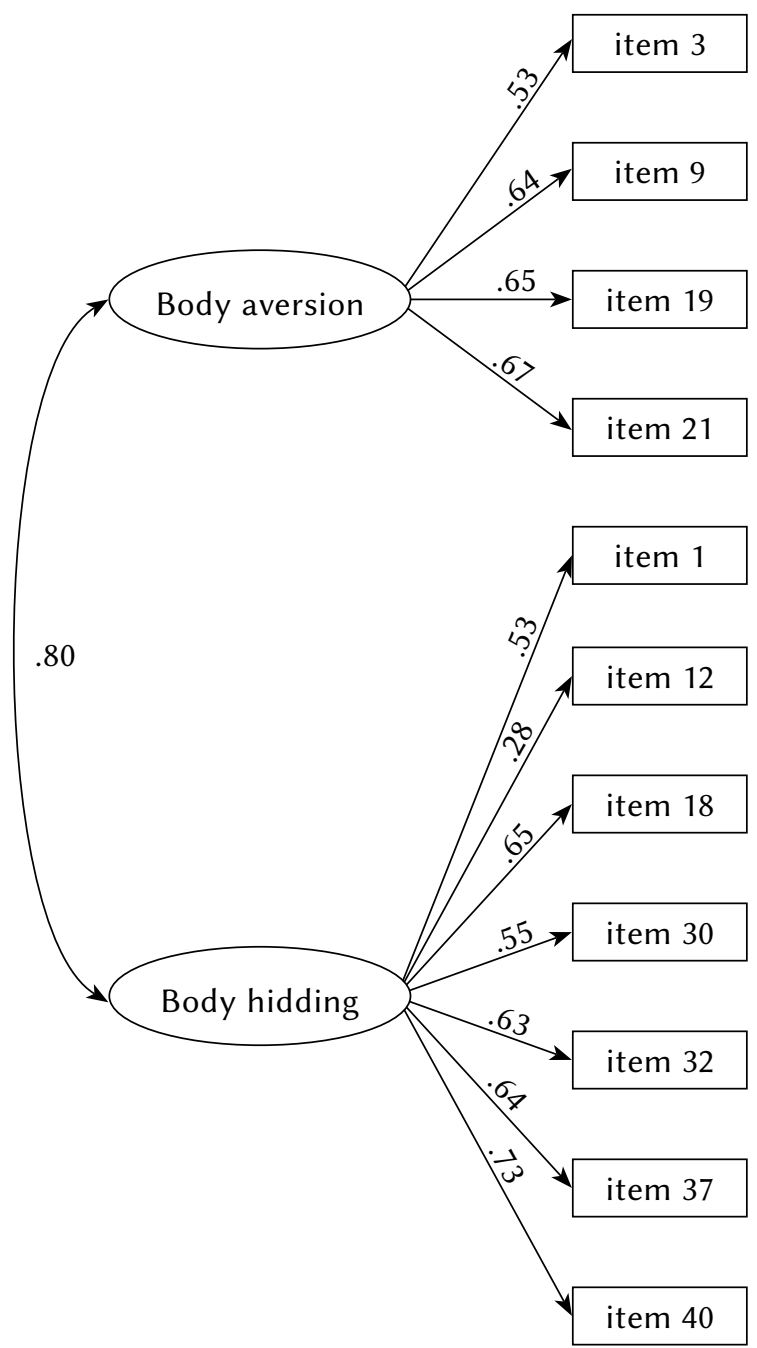

Figure 2. Factorial structure of the body stigma subscale in the Polish sample.

$12,18,30,32,37$, and 40 ), referred to self-pressure to hide one's body, avoidance of physical intimacy and feelings of being less attractive. As two items were redundant in their content (items 3 and 19 related to touching scars and avoidance related to physical: contact and intimacy), we added a covariance of their error terms into the model. The model fit parameters of this structural model were reasonable; RMSEA $=.070$, $\mathrm{CFI}=.932$. Inspection of factor loadings (Figure 2) revealed that item 12 (key-reversed) was a very poor indicator of body hiding (standardized coefficient of .276). Thus, we decided to test another model without this item. Fit parameters of the new model improved, indicating that the new model is more parsimonious (decrease in AIC of 848.183) and fitted our data; RMSEA $=.062, \mathrm{CFI}=.956$.

\section{Limitations}

The one-factor model of limitations scale revealed a reasonable model fit; $\mathrm{RMSEA}=.070, \mathrm{CFI}=.926$. Inspection of factor loadings indicated that loadings
Adaptation of Body Image after Breast Cancer Questionnaire in the Polish context 
of two items proved to be weak factor indicators (loadings of items 5 and 17 below .400). Inspection of modification indices suggested that adding covariance between items 5 and 6 , both indicative of an individual's daily arousal and related satisfaction, would increase the model fit (Figure 3). The analysis of the model fit including this change revealed an increase in fit parameters (decrease in AIC of 13.270); RMSEA $=.055, \mathrm{CFI}=.957$.
Romuald Derbis, Anna Machnik-Czerwik

\section{Body concerns}

Model fit parameters of the one-factor model were not acceptable; RMSEA $=.163, \mathrm{CFI}=.854$. As factor loadings of this model were satisfactory (above .400) we inspected modification indices. Based on that we added the covariance between two error terms of items 20 and 23, both related to dissatisfaction of particular areas of one's body (buttocks and hips), not dissatisfaction in general (other body concern items) (Figure 4). This modification improved the model fit parameters to a good model fit; RMSEA $=.046$ and $\mathrm{CFI}=.990$.

\section{Transparency and arm concerns}

Fit parameters of the one-factor model of the transparency subscale proved to be very poor; RMSEA = $=.152, \mathrm{CFI}=.889$. Analysis of factor loadings did not reveal problems within the subscale's indicators. Mod-

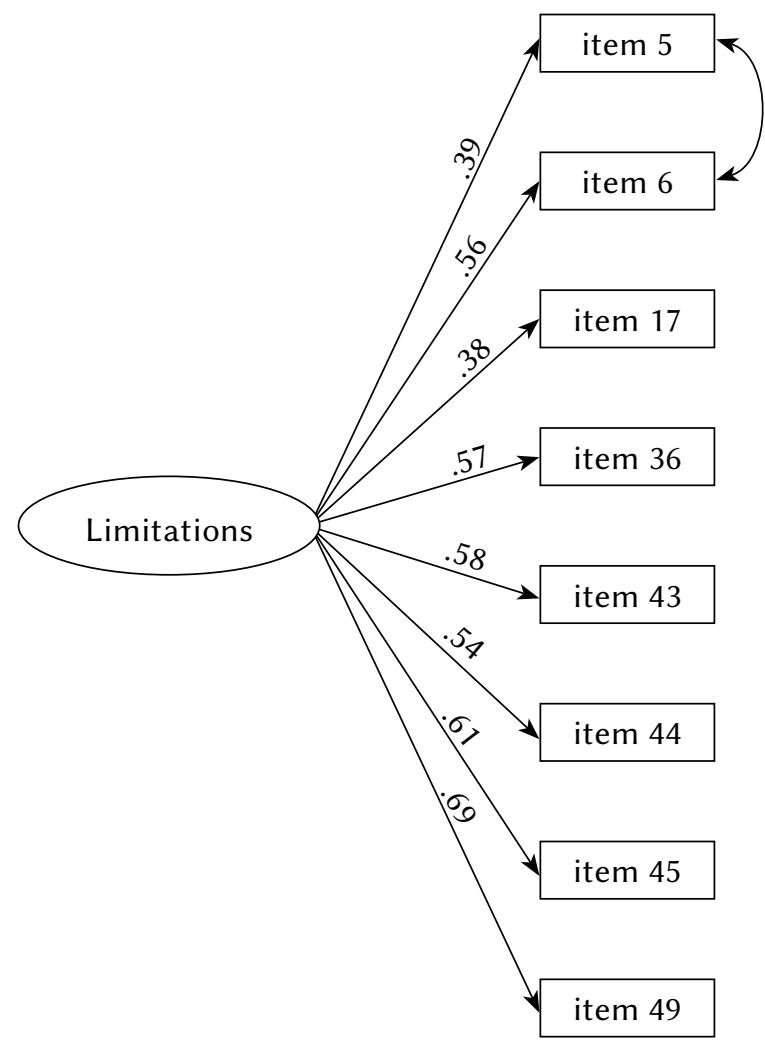

Figure 3. Factorial structure of the limitations subscale in the Polish sample. ification indices suggested that error terms of items 29 and 31 should be set to covary. This suggestion seems to be supported by the items' content analysis. Both items refer to subjective perception that people are looking at the respondent in general or her chest. Implementation of error covariances into the model improved the model fit parameters significantly; RMSEA $=.052$, CFI $=.990$.

The model fit parameters of the subscale indicative of arm concerns were not acceptable with regard to the error of approximation (RMSEA = .107); however, the comparative fit index was acceptable $(\mathrm{CFI}=.975)$. We investigated modification indexes and the content of items to find out whether any modification would be adequate and viable to increase the fit parameters. As only four items are used as indicators of this subscale and two of these are key-reversed and not related to pain or swelling but rather with normal arm sensations, we tested the new measurement model with correlated error terms of items 2 and 14. Although the error of approximation improved and yielded a mediocre fit (Browne \& Cudeck, 1993) $($ RMSEA $=.083)$, the subscale seems to be still relatively poorly fitted to the data.

Combining both subscales into one measurement model with transparency and arm concern latent factors (set to covary) revealed a reasonable model fit; RMSEA $=.065, \mathrm{CFI}=.952$ (Table 1 and Figure 5). The covariance between factors was positive and moderate in magnitude.

\section{Reliabilities and correlations between subscales}

As indicated in Table 2, estimation of composite reliabilities resulted in acceptable reliability values of all eight latent factors. Correlations between ob-

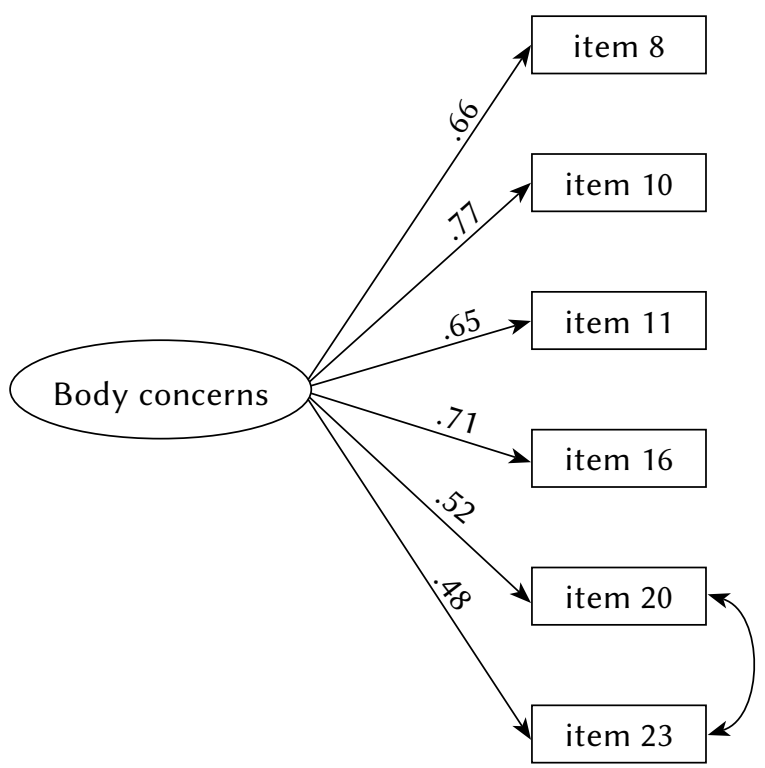

Figure 4. Factorial structure of the body concerns subscale in the Polish sample. 
servable factors (items' scores averaged within subscales) were mostly moderate, ranging from .29 to.66, indicating moderate overlap in subscales' content. The correlation between body perception and body worries within the vulnerability factor was high $(r=.65)$, indicating a strong overlap within the originally proposed subscale. Similarly, the correlation between body aversion and body hiding was strong $(r=.58)$, indicating content overlap between factors.

\section{Reliability of subscales}

The reliability of the BIBCQ subscales was measured by the omega coefficient, appropriate for latent factors, but alpha coefficients were also analyzed due to their popularity in research. Both are reported in Table 3 . The reliability of all subscales was acceptable in the Polish sample with regard to alpha and omega coefficients.

We also analyzed reliability of the BIBCQ subscales based on the split-half method with the oddeven system used to divide each subscale item pool into splits. We also used the Spearman-Brown formula to correct for the subscale's split lengths, which are smaller than in their unsplit form (the reliability coefficient increases as a function of the number of items). The Spearman-Brown coefficients for all subscales were as follows: .728 $(r=.57)$ for V-Body perception; $.833(r=.71)$ for V-Body worries; .757 $(r=.61)$ for BS-Body aversion; $.804(r=.67)$ for BSBody hiding; .731 $(r=.58)$ for Limitations; .736 $(r=.58)$ for Body concerns; .678 $(r=.51)$ for Arm concerns; and $.651(r=.48)$ for Transparency.

\section{STUDY 2}

Following the previous research (Baxter, 1998; Baxter et al., 2006) and our investigation of properties and
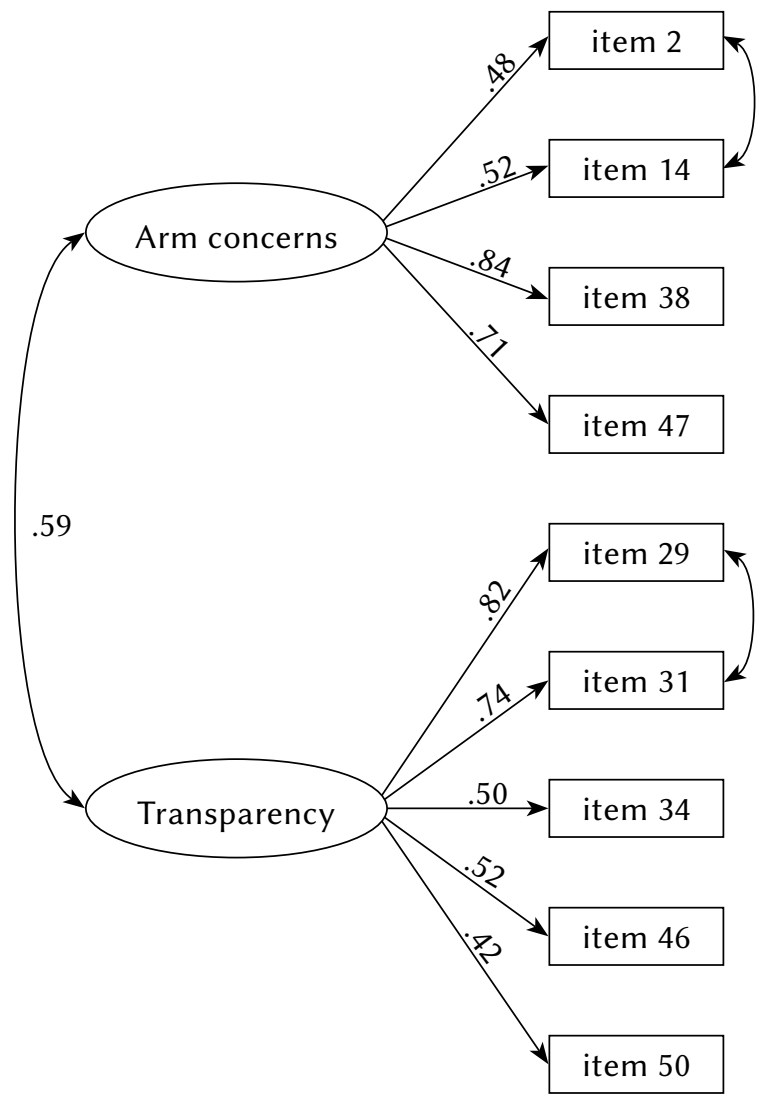

Adaptation of Body Image after Breast Cancer Questionnaire in the Polish context
Figure 5. Factorial structure of the transparency and the arm concerns subscales in the Polish sample.

the adequacy of the BIBCQ instrument in assessing the body image in women experiencing breast cancer in the Polish context, we asked a further question about the construct (convergent and divergent) and discriminant validity of our instrument.

Assessing convergent validity, we examined the degree in which the operationalization of our construct is similar to operationalization of other constructs that it should be similar to from a theoretical angle. Research indicates that some constructs may overlap with the body image addressing the

Table 2

The BIBCQ subscales' reliability omega (and alpha) coefficients and correlations between the BIBCQ subscales

\begin{tabular}{|c|c|c|c|c|c|c|c|c|}
\hline BIBCQ subscales & (1) & $(2)$ & (3) & (4) & (5) & (6) & $(7)$ & $(8)$ \\
\hline (1) V-Body perception & $.76(.76)$ & & & & & & & \\
\hline (2) V-Body worries & .65 & $.84(.84)$ & & & & & & \\
\hline (3) BS-Body aversion & .51 & .49 & $.69(.73)$ & & & & & \\
\hline (4) BS-Body hiding & .53 & .50 & .58 & $.79(.78)$ & & & & \\
\hline (5) Limitations & .44 & .54 & .44 & .45 & $.74(.76)$ & & & \\
\hline (6) Body concerns & .41 & .43 & .40 & .53 & .48 & $.74(.80)$ & & \\
\hline (7) Arm concerns & .29 & .38 & .36 & .36 & .46 & .38 & $.74(.74)$ & \\
\hline (8) Transparency & .53 & .66 & .48 & .43 & .49 & .36 & .36 & $.69(.74)$ \\
\hline
\end{tabular}

Note. All correlation coefficients are significant at the level of $p<.001 . \mathrm{V}-$ vulnerability, BS - body stigma. Reliability omega coefficients (composite reliability) are reported in the diagonals (Cronbach \& are reported in brackets). 
Table 3

Correlations between the BIBCQ subscales and scales used for its validation in Poland

Romuald Derbis, Anna Machnik-Czerwik

\begin{tabular}{|c|c|c|c|c|c|c|c|c|}
\hline \multirow{3}{*}{$\begin{array}{l}\text { Scales used for } \\
\text { validation }\end{array}$} & \multicolumn{8}{|c|}{ BIBCQ subscales in the Polish sample } \\
\hline & \multicolumn{2}{|c|}{ Vulnerability } & \multicolumn{2}{|c|}{ Body stigma } & \multirow{2}{*}{$\begin{array}{c}\text { Limita- } \\
\text { tions }\end{array}$} & \multirow{2}{*}{$\begin{array}{c}\text { Body } \\
\text { con- } \\
\text { cerns }\end{array}$} & \multirow{2}{*}{$\begin{array}{l}\text { Arm } \\
\text { con- } \\
\text { cerns }\end{array}$} & \multirow{2}{*}{$\begin{array}{c}\text { Trans- } \\
\text { parency }\end{array}$} \\
\hline & $\begin{array}{l}\text { V-Body } \\
\text { percep- } \\
\text { tion }\end{array}$ & $\begin{array}{l}\text { V-Body } \\
\text { worries }\end{array}$ & $\begin{array}{l}\text { BS-Body } \\
\text { aversion }\end{array}$ & $\begin{array}{l}\text { BS-Body } \\
\text { hiding }\end{array}$ & & & & \\
\hline Self-Esteem & -.14 & -.12 & $-.29^{* *}$ & $-.23^{*}$ & $-.33^{* *}$ & $-.27^{* *}$ & -.18 & $-.22^{*}$ \\
\hline Depression & $.34^{* * *}$ & $.36^{* * *}$ & $.36^{* * *}$ & $.38^{* * *}$ & $.46^{* * *}$ & $.24^{* * *}$ & $.33^{* * *}$ & $.44^{* * *}$ \\
\hline BR-23 - total & $.39^{* * *}$ & $.52^{* * *}$ & $.45^{* * *}$ & $.30^{* *}$ & $.50^{* * *}$ & $.37^{* * *}$ & $.50^{* * *}$ & $.48^{* * *}$ \\
\hline $\begin{array}{l}\text { BR-Body } \\
\text { appearance }\end{array}$ & $.46^{* * *}$ & $.52^{* * *}$ & $.53^{* * *}$ & $.51^{* * *}$ & $.51^{* * *}$ & $.51^{* * *}$ & $.40^{* * *}$ & $.55^{* * *}$ \\
\hline $\begin{array}{l}\text { BR-Sexual } \\
\text { functioning }\end{array}$ & -.15 & -.07 & $-.23^{*}$ & $-.28^{* *}$ & -.06 & -.07 & .01 & -.01 \\
\hline $\begin{array}{l}\text { BR-Side effects } \\
\text { of treat. }\end{array}$ & $.29^{* *}$ & $.29^{* *}$ & $.29^{* *}$ & .19 & $.39^{* * *}$ & $.27^{* *}$ & $.34^{* * *}$ & $.24^{*}$ \\
\hline $\begin{array}{l}\text { BR-Arm } \\
\text { symptoms }\end{array}$ & .19 & $.38^{* * *}$ & $.32^{* * *}$ & $.38^{* * *}$ & $.42^{* * *}$ & $.24^{*}$ & $.62^{* * *}$ & $.39^{* * *}$ \\
\hline $\begin{array}{l}\text { BR-Breast } \\
\text { symptoms }\end{array}$ & $.40^{* * *}$ & $.40^{* * *}$ & $.35^{* * *}$ & $.23^{*}$ & $.28^{* *}$ & $.27^{* *}$ & $.35^{* * *}$ & $.38^{* * *}$ \\
\hline $\begin{array}{l}\text { Social } \\
\text { desirability (KAS) }\end{array}$ & -.08 & -.11 & -.09 & -.08 & $-.22^{*}$ & $-.22^{*}$ & -.12 & -.16 \\
\hline $\begin{array}{l}\text { Ja Body Self } \\
\text { (BS) - total }\end{array}$ & $-.35^{* * *}$ & $-.43^{* * *}$ & $-.43^{* * *}$ & $-.54^{* * *}$ & $-.57^{* * *}$ & $-.59^{* * *}$ & $-.44^{* * *}$ & $-.50 * * *$ \\
\hline BS-Eating & $-.31^{* *}$ & $-.39 * * *$ & $-.29^{* *}$ & $-.27^{* *}$ & $-.33^{* * *}$ & $-.46^{* * *}$ & $-.25^{*}$ & $-.40 * * *$ \\
\hline $\begin{array}{l}\text { BS-Intimacy } \\
\text { with men }\end{array}$ & $-.42^{* * *}$ & $-.50 * * *$ & $-.51^{* * *}$ & $-.53^{* * *}$ & $-.50 * * *$ & $-.49^{* * *}$ & $-.43^{* * *}$ & $-.54^{* * *}$ \\
\hline $\begin{array}{l}\text { BS-Femininity } \\
\text { exposure }\end{array}$ & -.06 & -.03 & -.16 & $-.40 * * *$ & $-.45^{* * *}$ & $-.37^{* * *}$ & $-.23^{*}$ & -.04 \\
\hline $\begin{array}{l}\text { BS-Body } \\
\text { acceptance }\end{array}$ & $-.32^{* *}$ & $-.39^{* * *}$ & $-.36^{* * *}$ & $-.53^{* * *}$ & $-.57^{* * *}$ & $-.59 * * *$ & $-.47^{* * *}$ & $-.53^{* * *}$ \\
\hline
\end{tabular}

Note. ${ }^{*} p<.05,{ }^{* *} p<.01,{ }^{* *} p<.001$. BR-side effects of treat. - side effects of medical treatment. Point-biserial correlation was reported for correlation of the KAS with other scales.

convergent validity of the BIBCQ. High correlations were found between body image and other body image scales, self-esteem, depression, and life satisfaction (e.g., overview in Baxter, 1998; or Baxter et al., 2006). These results are based on the influence of body image on individual behavior, self-esteem, emotions, attitudes, decisions and social relations (Cash \& Pruzinsky, 2002). To estimate whether our construct adequately assesses body image, we decided to validate the BIBCQ by testing its correlations with similar body image measures, namely QLQ BR-23 (EORTC; Zawisza, Tobiasz-Adamczyk, Nowak, \& Kulig, 2010) and Body Self Questionnaire (Mirucka, 2005). Within the validation study of Baxter (1998, Baxter et al., 2006) moderate and strong correlations were found between the BIBCQ and body self scale, name- ly the Multidimensional Body - Self Relations Questionnaire.

Furthermore, we also tested the extent to which our scale assesses the constructs theoretically close to the body image, such as self-esteem and depression. According to Baxter (1998; Baxter et al., 2006) moderate correlations were found in many studies between body image and self-esteem as indicated by the Rosenberg Self-Esteem Inventory. Depression was also found to share common variance with the body image. Moreover, body image distortions are treated by Beck, in his popular Beck Depression Inventory, as cognitive indicators of depression. In general, depression is negatively related to body image, so depressed individuals tend to have a more negative body image (Baxter, 1998; Baxter et al., 2006). 
It is important to note that the convergence between depression, self-esteem and the body image may be especially salient in the group of women with cancer. The treatment of disease often introduces additional body image and health related problems, such as pain, nausea, hair loss or fatigue, which may trigger or increase depressive symptoms and decrease self-esteem. Thus, we expect that the body image of women with cancer may be negatively related to depression and positively to self-esteem.

The divergent validity demonstrates that the construct assessed by the target scale (the BIBCQ here) is different than the construct assessed by another scale under scrutiny (Kaplan \& Saccuzzo, 2005). Social desirability (socially desirable responding) is indicative of the individual (and culture-specific) tendency of people to present a favorable image of themselves. Divergent validity in our study was estimated using a social desirability scale, Kwestionariusz Aprobaty Społecznej (Drwal \& Wilczyńska, 1980).

To test the discriminant validity, as defined by Baxter, we analyzed whether our measure is viable to distinguish the body image of women who underwent mastectomy and lumpectomy surgery. Mastectomy is more invasive for the body and thus influential for the body image of women compared to lumpectomy, during which not the whole breast but only part of it is removed surgically. Therefore, we expected and tested the extent to which the BIBCQ score results would differ between the groups of women.

\section{PARTICIPANTS AND PROCEDURE}

\section{Measures}

The Rosenberg Self-Esteem Inventory (RSE) is a 10-item one-dimensional scale assessing self-esteem (Dzwonkowska, Lachowicz-Tabaczek, \& Łaguna, 2008). The 4-step Likert response format ranging from (1) Strongly agree to (5) Strongly disagree was used in our study. The reliability of the scale reported by the authors and indicated by the $\alpha$ coefficient ranged between .82 and .83 depending on the age of respondents.

The Beck Depression Inventory (BDI) is a measure of the severity of depression in adolescents and adults which consists of 21 symptoms and attitudes (Beck \& Steer, 1993; Parnowski \& Jernajczyk, 1977). A 4-point Likert response format was administered in the study and ranged from (1) never to (4) very often. The reliability of the scale, as indicated in the literature, was good with alpha between .86 and .89 (Kroemeke, 2011).

BR-23 is another scale used for validation in our study. The subscale assesses quality of life of women with breast cancer. The scale consists of 23 items and was developed to assess the body image of women with breast cancer (BR-23) and included the extended scales' tool EORTC QLQ. The BR-23 assesses the following body image dimensions: (1) body appearance, (2) sexual functioning, (3) side effects of treatment within (4) arm and (5) breast. The 4-step Likert response format used in this scale ranged from (1) never to (4) very often. The reliability of the BR-23 subscales indicated by the $\alpha$ coefficient was between .76 and .86 (Zawisza et al., 2010).

The body self construct was assessed using the Body Self Questionnaire of Mirucka (2005). The scale consists of 41 items and four subscales: (1) Intimacy with men, assessing experiences of women in intimate relations with men; (2) Own carnality/ body acceptance, indicating the degree of satisfaction related to the appearance of one's body and its shape; (3) Femininity exposure refers to acceptance and explicit exposure of own femininity attributes; (4) Eating items indicate the attitude a woman has toward eating and related body weight control behaviors. A 7-step Likert response format was used in the study and ranged from (0) Completely agree to (6) Completely disagree. Reliability of subscales was acceptable or good, ranging from .74 for Eating to .89 for Intimacy with men (Mirucka, 2005).

The social desirability scale, Kwestionariusz Aprobaty Społecznej, developed by Drwal and Wilczynska (1980), is a 29-item scale. The response format is two categorical with (1) true and (2) false categories. Reliability of the scale indicated by the KR-20 coefficient was .81 (Drwal \& Wilczyńska, 1980).

\section{Sample, procedure and statistical analyses}

The sample of 270 women after breast cancer used in Study 1 was also investigated in this study to test construct (convergent and divergent) validity. The Pearson correlation was used to analyze relations between variables with one exception. The relation between the social desirability scale with a two-categorical response format and other scales having multicategorical response formats was estimated using point-biserial correlation. Although treating 4-categorical variables as continuous may also be questionable, it is a widely used strategy which was also used in this study.

Aiming to test the discriminant validity of the BIBCQ instrument, a subsample of 60 women who had undergone mastectomy $(n=30)$ or lumpectomy $(n=30)$ was taken from our main sample. As only 30 women underwent lumpectomy surgery in our sample and 168 underwent mastectomy, we randomly selected a subsample of 30 women from the mastectomy sample in this part of the study. Differences between the groups were tested based on analysis of variance (ANOVA).

\section{RESULTS OF STUDY 2}

Correlations between subscales of the BIBCQ and scores of scales' used in Study 2 are reported in Table 3.
Adaptation of Body Image after Breast Cancer Questionnaire in the Polish context 
Romuald Derbis,

Anna

Machnik-Czerwik
Almost all correlations between eight subscales of the BIBCQ and other scales used as the criterion of convergent validity were moderate in magnitude. However, a few exceptions were found. First, vulnerability factors (body worries and body perception) were not correlated with self-esteem. Second, body self in its femininity exposure domain was also not related to vulnerability factors, body aversion or transparency. Furthermore, the BIBCQ was in general not related to sexual functioning indicated by the BR-23 scale, with the exception of body stigma.

Moreover, our study, unlike in Chinese culture (Zhang et al., 2014), and in line with the study of Baxter (1998), revealed a negative relation between depression and the body image. It means that the more negative body image the women report, the more likely they are also to be depressed.

Analyses testing divergent validity, as estimated by the correlation between the social desirability scale and the BIBCQ, revealed lack of significant correlations with the exception of two BIBCQ subscales - limitations and body concern - which were weakly and negatively related to the social desirability scale.

Finally, we analyzed discriminant validity by testing group differences in the body image between women who have undergone mastectomy or lumpectomy surgery. The results revealed three significant differences within eight BIBCQ subscales. First, the mean score of BS-body hiding was higher for the mastectomy group $(M=2.69, S D=.44)$ than for the lumpectomy group $(M=2.37, S D=.43), F(59)=6.55$, $p<.050$. Second, body concerns mean score was higher for the lumpectomy group $(M=3.47, S D=.90)$ than for the mastectomy group $(M=2.88, S D=.84)$, $F(59)=5.22, p<.050$. A similar result was found for arm concern, where the lumpectomy group $(M=2.96$, $S D=.57)$ scored higher than the mastectomy group $(M=2.59, S D=.47), F(59)=5.74, p<.050$.

\section{DISCUSSION}

Preliminary adaptation of the Body Image Breast Cancer Questionnaire (BIBCQ) and its construct validation in Polish culture were targeted in the present study. Although due to the sample size limitations our study is preliminary and the adaptation of the BIBCQ scale needs further investigation, our results indicated some differences regarding the factorial structure of the instrument compared to previous research. Validity of the scale was supported in our study, although some differences in comparison to previous studies also emerged.

\section{FACTORIAL STRUCTURE OF THE BIBCQ}

Although analyses carried out in the present study established the six factorial structure of the BIBCQ introduced by Baxter (1998, and Baxter et al., 2006), two out of six subscales were found to be bifactorial in our sample. The Vulnerability subscale included two latent factors of body perception and body worries. This statistically derived distinction seems to be rational from a theoretical angle and is based on the distinction between perception of own body suffering from cancer (agreement statements of Type I) and anger and worries related to the disease development (occurrence frequency statements of Type II). Even though the result has intuitive appeal, it also indicates that both experiences of one's body being overrun by the disease and worries are less interconnected in the Polish than in the Canadian sample.

The body stigma subscale introduced by Baxter was also found in our study to have a bifactorial structure consisting of body aversion and body hiding items. Body aversion was related to discomfort of the woman related to touching her scars but also with physical contacts with others (e.g., hugging). Body aversion also assessed feelings concerning own femininity. Body hiding referred to self-pressure to hide one's body, avoidance of physical intimacy and feelings of being less attractive. The distinction between them was based on exploration of our data (EFA), but also it seems to be reasonable from a theoretical perspective. Aversion is emotionally less engaging of own resources, and can be kept more at the implicit level, whereas body hiding additionally engages explicit behaviors (e.g., hiding) and is underlined not only by personal feelings but also behavioral effort. This distinction was also not represented in results from the Canadian sample reported by Baxter.

\section{CONSTRUCT VALIDATION OF THE BIBCQ}

Construct validity, defined through convergent and divergent validity, was also targeted in our study. Convergent validity, referring to similarity of our construct assessed by the BIBCQ measure to other measures assessing the same construct, was based on the assessment of the correlation between the BIBCQ and two measures - the BR-23 appearance (EORTC), and the Body Self Questionnaire (Mirucka, 2005). Additionally, we tested relations between the BIBCQ and two constructs theoretically similar to (overlapping with) the body image, namely self-esteem and depression. Most of our analyses supported the conclusion that the BIBCQ relates moderately to the scales mentioned above, with stronger correlations of the BIBCQ with BR-23 and Body self than with self-esteem and depression. Yet, a few exceptions were also found.

We did not find correlations between self-esteem and BIBCQ-vulnerability. We also did not find relations between BIBCQ-body aversion, BIBCQ-vulnerability and the femininity subscale of the body self instrument. It seems that arm concern and vulnera- 
bility items assess narrow, purely biological, symptoms of the disease, such as the expansion of cancer in the body and health worries, being relatively far less indicative for own body perception tackled more by other subscales of the BIBCQ. Therefore, we find the lack of vulnerability-self-esteem relation as reasonable and indicating that aspects related to the illness at its biological basis are not (as such) integral to a woman's self-esteem and are more likely to be perceived as an external traumatic factor which they experience as an obstacle not having any internal causes which might relate to self-esteem. Yet, this result is not in line with validation study results reported by Baxter (1998) and Baxter and colleagues (2006) where the vulnerability score was moderately negatively related to self-esteem (both indicated by the Rosenberg scale). It is possible however that social changes occurring after WW II related to social perception of cancer diseases in Poland has affected this result and cross-cultural differences. Cancer was commonly treated by individuals in Polish culture as a source of shame which was kept secret even within families still after WW II. We hypothesize that at the end of the $20^{\text {th }}$ century and the beginning of the $21^{\text {st }}$ century mass media in Poland might have influenced the change in social perception of cancer as a disease which is not caused by an individual, should be diagnosed as soon as possible and can happen to anyone without it being his or her fault. It is likely that the perception of cancer in Canada was never so negative as in Poland, and thus was not deliberately and explicitly altered through mass media in Canada. As a result the perception of cancer-related biological changes in one's body is weakly but stably bound with self-esteem in Canada as it was not the target of health policy and social change.

Our findings revealed that body aversion, transparency and vulnerability scores were not related to the aspect of body self, indicative of acceptance and emphasizing one's femininity. Although the same explanation proposed above and related to self-esteem seems also to fit a lack of vulnerability-femininity exposure relation, we suggest that a different interpretation should be formulated regarding the lack of relations between body self-femininity exposure and body aversion or transparency. It seems possible that different mechanisms underlie body aversion (biased by cancer-related changes) and the tendency to accept and expose one's femininity explicitly.

Analyses testing divergent validity and based on the analyses of the relation between the BIBCQ and social desirability scale carried out in our study supported in general the conclusion that the BIBCQ does not assess respondents' tendency to be perceived in a socially desirable manner. However, two exceptions were revealed. Two subscales of the BIBCQ, limitations and body concerns, were found to be weakly, but significantly and negatively related to the social desirability score. The result indicates that: (1) ex- plicit reporting of limitations related to one's body is likely to be accompanied by lower socially desirable self-promotion; and (2) women who report low satisfaction with their own body and appearance are also likely to express high social desirability tendencies. Thus, researchers who plan to use the BIBCQ scale in further studies should treat the score in limitation and body concern subscales with caution as the score of both may be contaminated by the variance shared with socially desirable responding style. However, as our study is preliminary, further studies using bigger samples should be carried to test both the scale structure and the effect of social desirability on responding.

Finally, by comparing women who have undergone lumpectomy and mastectomy surgery we also evidenced that the BIBCQ scale validly differentiates the body image between the two groups. Women after mastectomy reported a higher tendency and desire for body hiding than women after lumpectomy. Furthermore, body and arm concerns were higher for women after lumpectomy than after mastectomy. This result indicated that concerns related to arm and body are lower for women with less (not more invasive) surgical intervention. From a psychological point of view, arm and body concerns seem to be more marginal for women who have undergone mastectomy and struggle with more profound health problems threatening their life. In the same vein, women who have undergone lumpectomy, less invasive for their body and probably related to a less life-threatening stage of cancer, focus more on arm and body concerns central for their body image.

\section{LIMITATIONS OF THE STUDY}

Although our study has many strengths, it also has some limitations. First, $90.00 \%$ of the women with breast cancer included in our study were sampled in the Amazonki community. This sample of women may be specific regarding their cancer and body-related attitudes and may differ from women with cancer not joining the community meetings. Also, women in our study were subdivided based only on one criterion - the predominantly two-categorical type of surgery as part of cancer treatment. This decision may limit (Al-Ghazal et al., 2000; Mock, 1993; Machnik-Czerwik, 2014) comparisons of our results with results of previous studies reported by Baxter. Finally, the small sample size limited the extent of our analyses and conclusions regarding the factorial structure of the scale in the Polish context.

\section{RefEREnCES}

Al-Ghazal, S. K., Fallowfield, L., \& Blamey, R. W. (2000). Comparison of psychological aspects and patient satisfaction following breast conserving surgery,
Adaptation of Body Image after Breast Cancer Questionnaire in the Polish context 
simple mastectomy and breast reconstruction. European Journal of Cancer, 36, 1938-1943.

Ashing-Giwaa, K. T., Padilla, G. V., Bohorqueza, D. E., Tejeroa, J. S., \& Garcia, M. (2006). Understanding the breast cancer experience of Latina women. Journal of Psychosocial Oncology, 3, 19-52.

Baxley, O. K., Kendrick, E. L., \& Brown, H. E. (1984). Alopecia: Effect on cancer patients' body image. Cancer Nursing, 7, 499-503.

Baxter, N. N. (1998). The Body Image after Breast Cancer Questionnaire. The design and testing of a disease specific measure. Toronto: Graduate Department of Medical Sciences, University of Toronto.

Baxter, N. N., Goodwin, P. J., Mcleod, R. S., Dion, R., Devins, G., \& Bombardier, C. (2006). Reliability and validity of the Body Image after Breast Cancer Questionnaire. The Breast Journal, 12, 221-232.

Beck, A., \& Steer R. (1993). Beck Depression Inventory Manual. San Antonio, TX: Harcourt Brace.

Ben-Tovim, D., \& Walker, M. (1991). The development of Ben-Tovim Walker body attitudes questionnaire (BAQ), a new measures of women's attitudes towards their own bodies. Psychological Medicine, 21, 775-784.

Berscheid, E., Walster, E., \& Bohrnstedt, G. (1973). The happy American Body: A survey report. Psychology Today, 11, 119-131.

Boehmke, M. M., \& Dickerson, S. S. (2005). Symptom, symptom experiences, and symptom distress encountered by women with breast cancer undergoing current treatment modalities. Cancer Nursing, 5, 382-389.

Boquiren, V. M., Esplen, M. J., Wong, J., Toner, B., \& Warner, E. (2013). Exploring the influence of gender-role socialization and objectified body consciousness on body image disturbance in breast cancer survivors. Psycho-Oncology, 22, 2177-2185.

Brislin, R. W. (1980). Back-translation for cross-cultural research. Journal of Cross-Cultural Psychology, 1, 185-216.

Browne M. W., \& Cudeck R. (1993). Alternative ways of assessing model fit. In K. A. Bollen \& J. S. Long (eds.), Testing structural equation models (pp. 136162). Newbury Park, CA: Sage.

Cash, T. F. (2004). Body image: past, present, and future. Body Image, 1, 1-5.

Cash, T. F., \& Pruzinsky T. (1990). Body Images, Development, Deviance and Change. New York: The Guliford Press.

Cash, T. F \& Pruzinsky, T. (eds.). (2002). Body Image. A Handbook of Theory, Research and Clinical Practice. New York, London: The Guilford Press.

Chen, C. M., Cano, S. J., Klassen, A. F., King, T., McCarthy, C., Cordeiro, P. G., Morrow, M., \& Pusic, A. L. (2010). Measuring quality of life in oncologic breast surgery: a systematic review of patient-reported outcome measures. The Breast Journal, 6, 587-597.
Derbis, R. (2000). Doświadczanie codzienności poczucie jakości życia, swoboda działania, odpowiedzialność, wartości osób bezrobotnych [The experience of everyday life - the quality of life, freedom of action, responsibility, values of the unemployed]. Częstochowa: Wydawnictwo WSP.

Derbis, R. (2007). Poczucie jakości życia a zjawiska afektywne [The quality of life and affective phenomena]. In S. Kowalik (ed.), Spoteczne konteksty jakości życia [Social contexts of the quality of life] (pp. 13-52). Bydgoszcz: Wydawnictwo Wyższa Szkoła Gospodarki.

Drwal, R., \& Wilczyńska, J. (1980). Opracowanie Kwestionariusza Aprobaty Społecznej [The description of the Social Desirability Questionnaire]. Przeglad Psychologiczny, 23, 569-582.

Dzwonkowska, I., Lachowicz-Tabaczek, K., \& Łaguna, M. (2008). Samoocena i jej pomiar: polska adaptacja skali SES M. Rosenberga: podręcznik [Self-esteem and its measurement: Polish adaptation of the scale of SES M. Rosenberg: manual]. Warszawa: Pracownia Testów Psychologicznych PTP.

EORTC BR-23. Retrieved from: http://www.eortc.be/ qol/files/BR23/BR23\%20Polish.pdf (12.10.2013)

Fallbjörk, U., Rasmussen, B. H., Karlsson, S., \& Salander, P. (2013). Aspects of body image after mastectomy due to breast cancer - A two-year follow-up study. European Journal of Oncology Nursing, 17, 340-345.

Fung, K. W., Lau, Y., Fielding, R., Or, A., \& Wai Chun Yip, A. (2001). The impact of mastectomy, breast-conserving treatment and immediate breast reconstruction on the quality of life of Chinese women. ANZ Journal of Surgery, 71, 202-206.

Głębocka, A., \& Kulbat, J. (2005). Wizerunek ciała. Portret Polek [Body image. The portrait of Polish women] Opole: Wydawnictwo Uniwersytetu Opolskiego.

Goodwin, P.J., Ennis, M., Pritchard, K. L., McCready, D., Koo, J., Sidlofsky, S., Trudeau, M., Hood, N., \& Redwood, S. (1999). Adjuvant treatment and onset of menopause predict weight gain after breast cancer diagnosis. Journal of Clinical Oncology, 17, 120-129.

Goncalves, C. O., Gomes, M. C., Tavares, C. F., Neves, A. N., Campana, B., \& Cabello, C. (2014). Validation of the instrument "Body image after breast cancer" in Brazil. Motriz, Rio Claro, 20, 8-15.

Hu, L.-T., \& Bentler P. M. (1999). Cutoff criteria for fit indices in covariance structure analysis: Conventional criteria versus new alternatives. Structural Equation Modeling, 6, 1-55.

Izydorczyk, B., \& Bieńkowska, N. (2008). Obraz ja cielesnego - wybrane teoretyczne wątki rozumienia psychologicznych mechanizmów zjawiska [Bodily self image - selected theoretical motifs of understanding psychological mechanisms of the henomenon]. Problemy Medycyny Rodzinnej, 4, $52-58$. 
Kanatas, A.,Velikova, G., Roe, B., Horgan, K.Ghazali, N., Shaw, R. J., \& Rogers, S. N. (2012). Patient-reported outcomes in breast oncology: A review of validated outcome instruments. Tumori, 6, 678-688.

Kissane, D. W., Clarke, D. M., Ikin, J., Bloch, S., Smith, G. C., Vitetta, L., \& McKenzie, P. (1998). Psychological morbidity and quality of life in Australian women with early-stage breast cancer: A cross-sectional survey. Medicine Journal of Australia, 169, 192-196.

Kline, R. B. (2005). Principles and practice of Structural Equation Modeling ( $2^{\text {nd }}$ ed.). New York: The Guilford Press.

Konarski, R. (2010). Modele równań strukturalnych. Teoria i praktyka [Structural Equation Modeling. Theory and practice]. Warszawa: PWN.

Korkmaz, S., Goksuluk, D., \& Zararsiz, G. (2015). MVN: An $\mathrm{R}$ package for assessing multivariate normality. Retrieved from: http://www.personality-project.org/r (10.11.2013).

Kowalik, S. (2000). Jakość życia psychicznego [The quality of psychological life]. In R. Derbis (ed.), Jakość rozwoju a jakość życia [The quality of development and the quality of life] (pp. 11-32). Częstochowa: Wydawnictwo Wyższej Szkoły Pedagogicznej.

Kowalik, S. (2007). Jakość życia związana ze stanem zdrowia [The quality of life related with the health condition]. In S. Kowalik (ed.), Spoteczne konteksty jakości życia [Social contexts of the quality of life] (pp. 147-171). Bydgoszcz: Uczelniane WSG.

Kowalik, S. (2009). Ja cielesne w psychologii rehabilitacji [Body self in psychology of rehabilitation]. Czasopismo Psychologiczne, 2, 305-320.

Kroemeke, A. (2011). Rola pozytywnych i negatywnych afektów w procesie radzenia sobie ze stresem osób po zawale serca [The role of positive and negative affects in stress coping process of patients after myocardial infarction]. Psychologia Jakości Życia, 1, 1-19.

Lipowska, M., \& Lipowski, M. (2013). Polish normalization of the Body Esteem Scale. Health Psychology Report, 1, 72-81.

Machnik-Czerwik, A. (2014). Obraz ciała i poczucie jakości życia kobiet z rakiem piersi [Body image and the quality of life perception in women with breast cancer]. Unpublished manuscript of doctoral thesis. Casimir the Great Univerity in Bydgoszcz.

Mirucka, B. (2005). Kwestionariusz Ja Cielesnego (Skala J-C) [Body self questionnaire (the J-C scale)]. Przeglad Psychologiczny, 48, 313-329.

Mirucka, B. (2003). Poszukiwanie znaczenia cielesności i ja cielesnego [In the search of carnality and body-self]. Przegląd Psychologiczny, 2, 209-223.

Mirucka, B., \& Sakson-Obada, O. (2013). Ja cielesne: od normy do zaburzeń [Body Self. When a norm becomes a disorder]. Gdańsk: GWP.
Mock, V. (1993). Body image in women treated for breast cancer. Nursing Research, 42, 153-157.

Montazeri, A. (2008). Health-related quality of life in breast cancer patients: A bibliographic review of the literature from 1974 to 2007. Journal of Experimental \& Clinical Cancer Research, 27, 1-31.

Parnowski, T., \& Jernajczyk, W. (1977). Inwentarz Depresji Becka w ocenie nastroju osób zdrowych i chorych na choroby afektywne [The use of the Beck Depression-Inventory in mood estimation in helathy individuals and individuals with affective disorders]. Psychiatria Polska, 11, 417-421.

Paterson, C. L., Lengacher, C. A., Donovan, K. A., Kip, K. E., \& Tofthagen, C. S. (2016). Body Image in Younger Breast Cancer Survivors: A Systematic Review. Cancer Nursin, 39, E39-58.

Pinto, B., \& Trunzo, J. (2004). Body esteem and mood among sedentary and active breast cancer survivors. Mayo Clinic Proceeding, 79, 181-186.

$\mathrm{R}$ Core Team (2014). R: A language and environment for statistical computing. From: http://www.personality-project.org/r (Retrieved 1.11.2012).

Raykov, T. (2001). Estimation of congeneric scale reliability using covariance structure analysis with nonlinear constraints. British Journal of Mathematical and Statistical Psychology, 54, 315-323.

Revelle, W. (2011). Package 'psych'. Retrieved from: http://www.personality-project.org/r (10.11.2013).

Rosseel, Y. (2012). lavaan: An R Package for Structural Equation Modeling. Journal of Statistical Software, 48, 1-36.

Satorra, A., \& Bentler, P. M. (1994). Corrections to test statistics and standard errors in covariance structure analysis. In A. von Eye, \& C. C. Clogg (eds.), Latent variables analysis: Applications to developmental research (pp. 399-419). Thousand Oaks: Sage.

Schier, K. (2009). Piękne brzydactwo [The beautiful eyesore]. Warsaw: Scholar.

Schou, I., Ekeberg, R., Sandvik, L., Hjermstad, M. J., \& Ruland, C. M. (2005). Multiple predictors of health-related quality of life in early stage breast cancer. Data from a year follow-up study compared with the general population. Quality of Life Research, 14, 1813-1823.

Slade, P. D. (1994). What is body image? Behaviour Research and Therapy, 32, 497-502.

Statistical Office in Krakow. (2012). Zdrowie kobiet w Polsce w latach 2004-2009 [The health of women in Poland between 2004 and 2009]. Retreived from: http://www.stat.gov.pl (12.08.2015).

Stavrou, D., Weissman, O., Polyniki, A., Papageorgiou, N., Haik, J., Farber, N., \& Winkler, E. (2009). Quality of life after breast cancer surgery with or without reconstruction. Eplasty, 9, e18. Retrieved from: http://www.ncbi.nlm.nih.gov/pmc/articles/ PMC2691644/ (5.11.2015).
Adaptation of Body Image after Breast Cancer Questionnaire in the Polish context 
Vamos, M. (1993). Body image in chronic illness a reconceptualization. International Journal of Psychiatry in Medicine, 2, 163-178.

Zawisza, K., Tobiasz-Adamczyk, B., Nowak, W., \& Kulig, J. (2010). Trafność i rzetelność kwestionariusza oceny jakości życia EORTC QLQ C-30 oraz jego modułu dotyczącego nowotworu piersi (EORTC QLQ BR-23) [Validity and reliability of the quality of life questionnaire (EORTC QLQ C30) and its breast cancer module (EORTC QLQ

Romuald Derbis,

Anna Machnik-Czerwik BR23)]. Ginekologia Polska, 81, 262-267.

Zhang, J., Zhu, X., Tang, L., Chen, G., Wang, Y., Yang, Y., \& Li, L. (2014). Psychometric features of the body image after breast cancer questionnaire - Chinese version in women with breast cancer. Journal of Central South University, 39, 73-77. 
KOC-RP

\section{INSTRUKCJA}

Poniższe strony zawierają twierdzenia mówiące o tym, jak kobiety mogą myśleć, czuć się lub zachowywać po zachorowaniu na raka piersi. Prosimy zaznaczyć, jak każde z poniższych stwierdzeń odnosi się do Pani osobiście na przestrzeni ostatniego miesiąca.

\section{INSTRUCTIONS}

The following pages contain statements about how women might think, feel, or behave after the diagnosis of the breast cancer. Please, indicate how adequately each of following statements describes you over last month. Please read each statement carefully and indicate how it applies to you. While answering, consider how you have felt over the past month.

W każdym wierszu należy zaznaczyć jedną, najbardziej właściwą dla siebie odpowiedź, otaczając kółkiem odpowiednią cyfrę (1-2-3-4-5). Nie należy opuszczać żadnego stwierdzenia. Poszczególne cyfry oznaczają: Using the scales ranging from 1 to 5 (1-2-3-4-5) following each statement, indicate how adequately the statement fits to you. Be careful not to omit any statement.

Twierdzenia pierwszego typu / First type of statement

1 - całkowicie się nie zgadzam / Strongly Disagree

2 - nie zgadzam się / Disagree

3 - nie potwierdzam i nie zaprzeczam / Neither Agree nor Disagree

4 - zgadzam się / Agree

5 - całkowicie się zgadzam / Strongly Agree

\begin{tabular}{|c|c|c|c|c|c|c|}
\hline 1 & Próbuję ukrywać moje ciało / I try to hide my body & 1 & 2 & 3 & 4 & 5 \\
\hline 2 & Uczucie w ramieniu jest normalne / The feeling in my arm is normal & 1 & 2 & 3 & 4 & 5 \\
\hline 3 & $\begin{array}{l}\text { Unikam patrzenia na blizny po operacji piersi / I avoid looking at my scars from breast } \\
\text { surgery }\end{array}$ & 1 & 2 & 3 & 4 & 5 \\
\hline 4 & Czuję się, jakbym w środku miała bombę / I feel there is a time bomb inside of me. & 1 & 2 & 3 & 4 & 5 \\
\hline 5 & Jestem senna w ciągu dnia / I am sleepy during the day & 1 & 2 & 3 & 4 & 5 \\
\hline 6 & Jestem zadowolona z poziomu mojej energii / I am happy with my level of energy & 1 & 2 & 3 & 4 & 5 \\
\hline 7 & Czuję, że jestem podatna na raka / I feel prone to cancer & 1 & 2 & 3 & 4 & 5 \\
\hline 8 & $\begin{array}{l}\text { Jestem usatysfakcjonowana kształtem mojego ciała / I am satisfied with the shape of } \\
\text { my body }\end{array}$ & 1 & 2 & 3 & 4 & 5 \\
\hline 9 & $\begin{array}{l}\text { Czuję się mniej kobieco od momentu zachorowania na raka / I feel less feminine since } \\
\text { cancer }\end{array}$ & 1 & 2 & 3 & 4 & 5 \\
\hline 10 & Lubię swoje ciało / I like my body & 1 & 2 & 3 & 4 & 5 \\
\hline 11 & $\begin{array}{l}\text { Czuję się dobrze z tym, jak wyglądam, kiedy ćwiczę / I feel comfortable about the way } \\
\text { I look when I exercise }\end{array}$ & 1 & 2 & 3 & 4 & 5 \\
\hline 12 & $\begin{array}{l}\text { Czułabym się swobodnie, korzystając z publicznej przebieralni / I would feel comfort- } \\
\text { able changing in a public change-room }\end{array}$ & 1 & 2 & 3 & 4 & 5 \\
\hline 13 & Czuję, że moje ciało przeżyło inwazję / I feel my body has been invaded & 1 & 2 & 3 & 4 & 5 \\
\hline 14 & $\begin{array}{l}\text { Jestem usatysfakcjonowana wyglądem mojego ramienia / I am satisfied with the ap- } \\
\text { pearance of my arm }\end{array}$ & 1 & 2 & 3 & 4 & 5 \\
\hline 15 & Czuję, że moje ciało mnie zawiodło / I feel my body has let me down & 1 & 2 & 3 & 4 & 5 \\
\hline 16 & Lubię mój wygląd taki jakim jest / I like my looks just the way they are & 1 & 2 & 3 & 4 & 5 \\
\hline 17 & Inni musieli przejąć moje obowiązki / Others have had to take over my duties & 1 & 2 & 3 & 4 & 5 \\
\hline 18 & $\begin{array}{l}\text { Czuję, że część mnie musi pozostać w ukryciu / I feel that part of me must remain } \\
\text { hidden }\end{array}$ & 1 & 2 & 3 & 4 & 5 \\
\hline 19 & $\begin{array}{l}\text { Boję się dotykać blizn po operacji piersi / I am afraid of touching the scars from breast } \\
\text { surgery }\end{array}$ & 1 & 2 & 3 & 4 & 5 \\
\hline
\end{tabular}

Adaptation of Body Image after Breast Cancer Questionnaire in the Polish context 


\begin{tabular}{|c|c|c|c|c|c|c|}
\hline 20 & $\begin{array}{l}\text { Jestem usatysfakcjonowana wyglądem moich bioder / I am satisfied with the appear- } \\
\text { ance of my hips }\end{array}$ & 1 & 2 & 3 & 4 & 5 \\
\hline 21 & $\begin{array}{l}\text { Unikam bliskiego fizycznego kontaktu, takiego jak przytulanie / I avoid close physical } \\
\text { contact such as hugging }\end{array}$ & 1 & , & 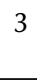 & 4 & 5 \\
\hline 22 & $\begin{array}{l}\text { Czuję, że coś przejmuje kontrolę nad moim ciałem / I feel that something is taking over } \\
\text { my body }\end{array}$ & 1 & 2 & 3 & 4 & 5 \\
\hline 23 & $\begin{array}{l}\text { Jestem usatysfakcjonowana kształtem moich pośladków / I am satisfied with the shape } \\
\text { of my buttocks }\end{array}$ & 1 & 2 & 3 & 4 & 5 \\
\hline
\end{tabular}

Romuald Derbis,

Anna

Machnik-Czerwik

*Poniższe pytania odnoszą się do uczuć dot. piersi lub miejsca po mastektomii. Jeśli straciła Pani pierś(si) (jeśli miała Pani mastektomię bez rekonstrukcji piersi), prosimy odpowiedzieć na pytanie 24. Jeśli ma Pani obie piersi (jeśli miała Pani wycinany guzek piersi, mastektomię z rekonstrukcją piersi lub Pani pierś nie była poddana chirurgicznej interwencji), prosimy opuścić pytanie 24 i odpowiedzieć na pytania od 25 do 28.

* Statements below refer to feelings related with breast or the morning after the mastectomy. If your breast(s) was/were surgically removed (if you had mastectomy without breast reconstruction), please, answer the question $\mathrm{nr} 24$. If you have both breasts (having only a breast lump cut, mastectomy with breast reconstruction, or your breast was not under any surgical intervention) skip item nr 24 and answer items from 25 to 28 .

Kobiety, które mają jedną pierś bądź nie mają obu piersi powinny odpowiedzieć na poniższe pytanie. The following statements are addressed to women who have any or one breast.

\begin{tabular}{|l|l|l|l|l|l|l|}
\hline 24 & $\begin{array}{l}\text { Czuję się swobodnie, patrząc na miejsce po mastektomii* / I feel comfortable looking } \\
\text { at my mastectomy* }\end{array}$ & 1 & 2 & 3 & 4 & 5 \\
\hline
\end{tabular}

Kobiety, które mają obie piersi powinny odpowiedzieć na poniższe pytania.

The following statements are addressed to women who have both breasts.

\begin{tabular}{|c|c|c|c|c|c|c|}
\hline 25 & $\begin{array}{l}\text { Jestem zadowolona z umiejscowienia mojego sutka* / I am happy with the position of } \\
\text { my nipple* }\end{array}$ & 1 & 2 & 3 & 4 & 5 \\
\hline 26 & $\begin{array}{l}\text { Jestem usatysfakcjonowana rozmiarem moich } \text { piersi }^{*} / \text { I am satisfied with the size of } \\
\text { my breast }{ }^{*}\end{array}$ & 1 & 2 & 3 & 4 & 5 \\
\hline 27 & $\begin{array}{l}\text { Czuję się swobodnie, gdy inni widzą moje piersi* / I feel comfortable when others see } \\
\text { my breasts* }\end{array}$ & 1 & 2 & 3 & 4 & 5 \\
\hline 28 & $\begin{array}{l}\text { Wygląd moich piersi mógłby przeszkadzać innym* / The appearance of my breast } \\
\text { could disturb others* }\end{array}$ & 1 & 2 & 3 & 4 & 5 \\
\hline
\end{tabular}

Twierdzenia drugiego typu / Type two statements responses

1 - nigdy/prawie nigdy / Never/Almost Never

2 - nieczęsto / Infrequently

3 - czasami / Sometimes

4 - często / Often

5 - zawsze/prawie zawsze / Always/Almost Always

\begin{tabular}{|c|c|c|c|c|c|c|}
\hline 29 & $\begin{array}{l}\text { Czuję, że ludzie patrzą się na moją klatkę piersiową / I feel that people are looking at } \\
\text { my chest }\end{array}$ & 1 & 2 & 3 & 4 & 5 \\
\hline 30 & Unikam fizycznej intymności / I avoid physical intimacy & 1 & 2 & 3 & 4 & 5 \\
\hline 31 & Czuję, że ludzie się na mnie patrzą / I feel that people are looking at me & 1 & 2 & 3 & 4 & 5 \\
\hline 32 & Ukrywam moje ciało podczas przebierania się / I hide my body when changing clothes & 1 & 2 & 3 & 4 & 5 \\
\hline 33 & Martwię się, że rak się rozprzestrzenia / I worry that the cancer is spreading & 1 & 2 & 3 & 4 & 5 \\
\hline 34 & $\begin{array}{l}\text { Potrzebuję zapewnień na temat wyglądu mojego biustu / I need to be reassured about } \\
\text { the appearance of my bust }\end{array}$ & 1 & 2 & 3 & 4 & 5 \\
\hline 35 & Myślę o moim raku piersi / I think about breast cancer & 1 & 2 & 3 & 4 & 5 \\
\hline 36 & Zmęczenie przeszkadza mi w życiu / Being tired interferes with my life & 1 & 2 & 3 & 4 & 5 \\
\hline 37 & $\begin{array}{l}\text { Czuję się seksualnie atrakcyjna, kiedy jestem naga / I feel sexually attractive when } \\
\text { I am nude }\end{array}$ & 1 & 2 & 3 & 4 & 5 \\
\hline
\end{tabular}




\begin{tabular}{|c|c|c|c|c|c|c|}
\hline 38 & $\begin{array}{l}\text { Puchnięcie mojego ramienia stanowi dla mnie problem / Swelling of my arm is a prob- } \\
\text { lem for me }\end{array}$ & 1 & 2 & 3 & 4 & 5 \\
\hline 39 & Martwię się o moje ciało / I worry about my body & 1 & 2 & 3 & 4 & 5 \\
\hline 40 & $\begin{array}{l}\text { chest covered during sexual intimacy } \\
\text { col }\end{array}$ & 1 & 2 & 3 & 4 & 5 \\
\hline 41 & Czuję, że jestem zła na moje ciało / I feel angry at my body & 1 & 2 & 3 & 4 & 5 \\
\hline 42 & (1) & 1 & 2 & 3 & 4 & 5 \\
\hline 43 & normal activities & 1 & 2 & 3 & 4 & 5 \\
\hline 44 & Lam problemy z koncentracją / I have problems concentrating & 1 & 2 & 3 & 4 & 5 \\
\hline 45 & 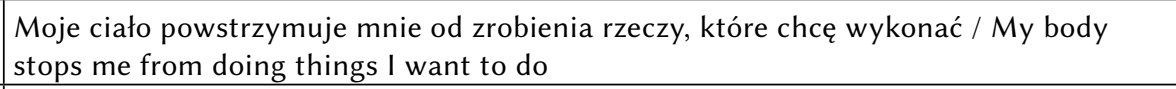 & 1 & 2 & $\mathrm{~S}$ & F & 5 \\
\hline 46 & $\begin{array}{l}\text { Myślę, że moje piersi wydają się innym nierówne / I think my breasts appear uneven } \\
\text { to others }\end{array}$ & 1 & 2 & 3 & 4 & 5 \\
\hline 47 & Ból ramienia jest dla mnie problemem / Arm pain is a problem for me & 1 & 2 & 3 & 4 & 5 \\
\hline 48 & $\begin{array}{l}\text { Martwię się najmniejszymi bólami i dolegliwościami / I worry about minor aches and } \\
\text { pains }\end{array}$ & 1 & 2 & 3 & F & 5 \\
\hline 49 & Czuję się normalnie / I feel normal & 1 & 2 & 3 & 4 & 5 \\
\hline 50 & $\begin{array}{l}\text { Czuję, że ludzie mogą powiedzieć, iż moje piersi nie są normalne / I feel people can tell } \\
\text { my breasts are not normal }\end{array}$ & 1 & 2 & 3 & 4 & 5 \\
\hline
\end{tabular}

*Poniższe pytania odnoszą się do uczuć dot. piersi lub miejsca po mastektomii. Jeśli straciła Pani pierś(si) (jeśli miała Pani mastektomię bez rekonstrukcji piersi), prosimy odpowiedzieć na pytanie 51. Jeśli ma Pani obie piersi (jeśli miała Pani wycinany guzek piersi, mastektomię z rekonstrukcją piersi lub Pani pierś nie była poddana chirurgicznej interwencji), prosimy opuścić pytanie 51 i odpowiedzieć na pytania 52 i 53.

* Statements below refer to feelings related with breast or the morning after the mastectomy. If your breast(s) was/were surgically removed (if you had mastectomy without breast reconstruction), please, answer the question $\mathrm{nr}$ 51. If you have both breasts (having only a breast lump cut, mastectomy with breast reconstruction, or your breast was not under any surgical intervention) skip item nr 51 and answer items from 52 to 53 .

Kobiety, które mają jedną pierś bądź nie mają obu piersi, powinny odpowiedzieć na poniższe pytanie. The following statements are addressed to women who have any or one breast.

\begin{tabular}{|l|l|l|l|l|l|l|}
\hline 51 & $\begin{array}{l}\text { Martwię się, aby moja proteza lub wkładka się nie obsunęły* / I worry about my pros- } \\
\text { thesis or padding slipping* }\end{array}$ & 1 & 2 & 4 & 5 \\
\hline
\end{tabular}

Kobiety, które mają obie piersi powinny odpowiedzieć na poniższe pytania.

The following statements are addressed to women who have both breasts.

\begin{tabular}{|c|c|c|c|c|c|c|}
\hline 52 & Myślę o mojej piersi* / I think about my breast* & 1 & 2 & 3 & 4 & 5 \\
\hline 53 & Moja pierś boli przy dotykaniu* / My breast is painful to touch* & 1 & 2 & 3 & 4 & 5 \\
\hline
\end{tabular}

